\title{
Tratamento ortodôntico voltado para a dentadura decídua
}

Foi com grande sucesso que se desenvolveu o Curso do Prof. Omar Gabriel da Silva Filho nos dias 10 e 11 de março de 2007 realizado nas dependências do Hotel EZ Aclimação, organizado pelo Departamento Científico da APCD Regional Cambuci. O curso abrangeu o tema "Tratamento ortodôntico voltado para a Dentadura Decídua”. Na foto estão os alunos junto com o Prof Omar Gabriel. O evento teve o patrocínio da Revista Dental Press de Ortodontia e Ortopedia Facial.

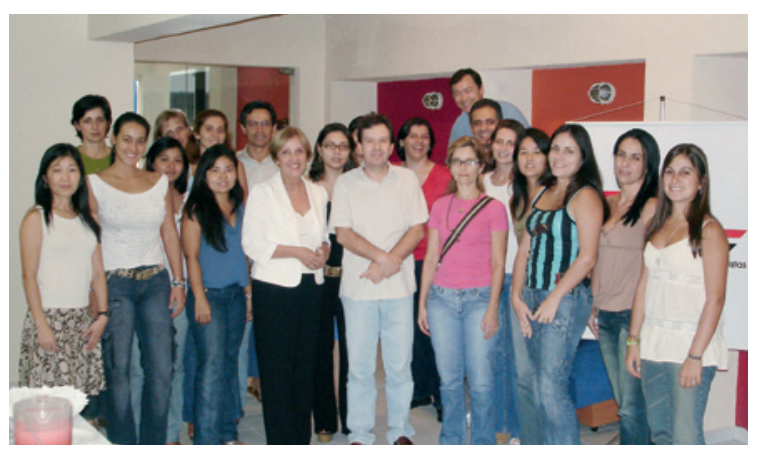

\section{Estratégias biomecânicas e estéticas na clínica ortodôntica}

Esta notável obra é um guia completo da biomecânica na clínica ortodôntica. Uma ampla abordagem demonstra claramente como os princípios da biomecânica podem ser aplicados para todas as técnicas ortodônticas a fim de aperfeiçoar o emprego das forças, prevenir efeitos colaterais e alcançar resultados previsíveis.

Ainda, neste livro:

- Muitas imagens clínicas coloridas, com acompanhamento de desenhos esquemáticos que esclarecem técnicas e conceitos importantes.

- Tópicos avançados, tais como ancoragens esqueléticas, conceitos de estética, tratamentos interdisciplinares, fatores biomecânicos, biologia do movimento dentário e tendências atuais na Ortodontia.

- Informações dos últimos avanços na utilização e seleção dos fios ortodônticos, apresentando todas as opções viáveis para auxiliar a estabelecer as decisões clínicas.

- Cobertura abrangente de diagnóstico, plano de tratamento e estratégias biomecânicas que direcionam a soluções de problemas ortodônticos diversos.

- Informações de utilização de modalidades de tratamento sem extração, como o arco extrabucal, Herbst, molas de memória de forma e outros métodos no campo dos resultados previsiveis.
- Técnicas-chave para tratamento de má oclusão, incluindo simples mudanças nas dobras de arcos que podem aperfeiçoar enormemente a qualidade dos movimentos dentários.

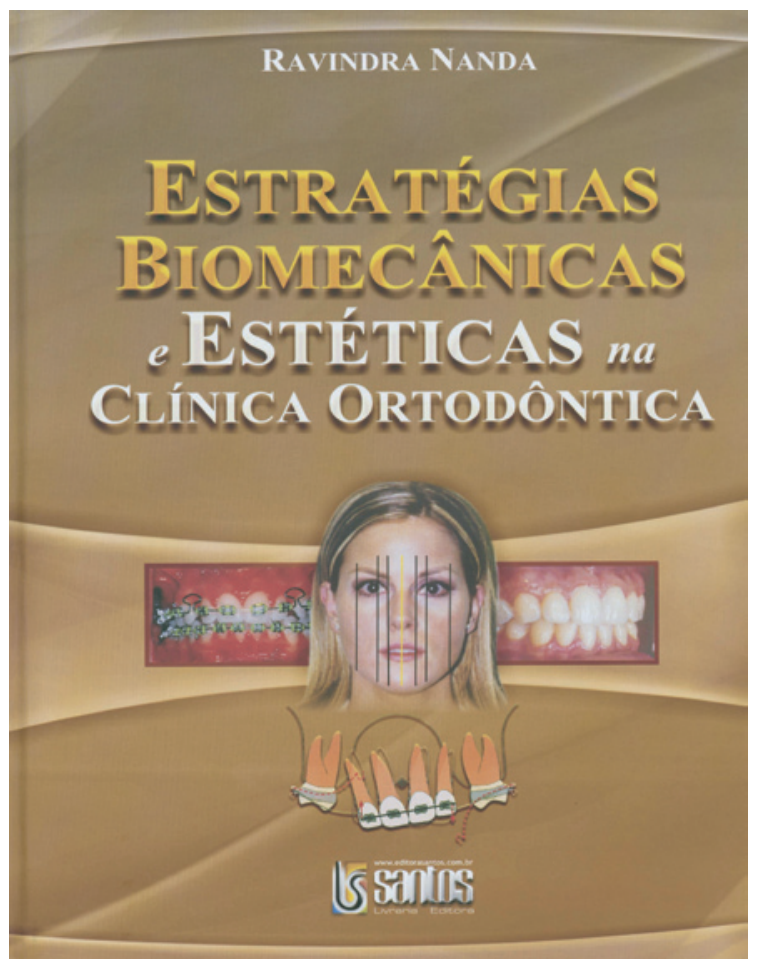

